Dicle Tıp Dergisi / Dicle Med J (2019) 46 (4) : 789 - 797

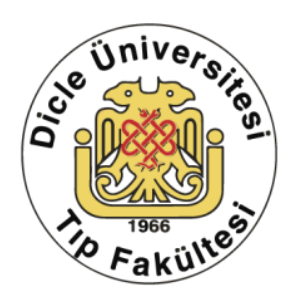

WWW.diclemedj.org

Özgün Araştırma / Original Article

\title{
Etkin Eğitim Müdahalesi HIV Hastalarında Uyumu İlaç Pozolojisinden Bağımsız Olarak Etkiler mi?
}

\author{
İrem Akdemir Kalkan'1, Ömer Karaşahin'2, Tuba Dal'3, Meryem Merve Ören"4, \\ Merve Ayhan ${ }^{5}$, Yakup Demir'6, Yeșim Yıldız ${ }^{7}$, Fesih Aktar ${ }^{8}$, Mustafa Kemal Çelen ${ }^{9}$
}

1 Ankara Üniversitesi Tıp Fakültesi, Enfeksiyon Hastallkları ve Klinik Mikrobiyoloji, Ankara, Türkiye ORCID: 0000-0001-5136-9148

2 Erzurum Bölge Eğitim Araștırma Hastanesi, Enfeksiyon Hastalıkları ve Klinik Mikrobiyoloji, Erzurum, Türkiye ORCID: 0000-0001-7045-1462

3 Ankara Yıldırım Beyazıt Üniversitesi, Tıbbi Mikrobiyoloji, Ankara, Türkiye ORCID: 0000-0002-4245-1534

4 İstanbul Üniversitesi Tıp Fakültesi, Halk Sağlı̆̆ı, İstanbul, Türkiye ORCID: 0000-0002-3383-7830

5 Serbest Eczacl, Batman, Türkiye ORCID: 0000-0003-3145-4059

6 Dicle Üniversitesi Tıp Fakültesi, Enfeksiyon Hastalıkları ve Klinik Mikrobiyoloji, Diyarbakır, Türkiye ORCID: 0000-0003-2419-3436

7 Mardin Devlet Hastanesi, Enfeksiyon Hastalıkları ve Klinik Mikrobiyoloji, Mardin, Türkiye ORCID: 0000-0003-3006-4112

8 Dicle Üniversitesi Tıp Fakültesi, Cocuk Sağlı̆ıı ve Hastalıkları, Diyarbakır, Türkiye ORCID: 0000-0002-0760-5681

9 Dicle Üniversitesi Tıp Fakültesi, Enfeksiyon Hastalıkları ve Klinik Mikrobiyoloji, Diyarbakır, Türkiye ORCID: 0000-0001-5876-2241

Geliş: 27.08.2019; Revizyon: 21.10.2019; Kabul Tarihi: 29.10.2019

\section{Öz}

Amaç: Ülkemizde 2017 verileriyle 17.000 kişinin HIV (insan immün yetmezlik virüsü) ile enfekte olduğu bilinmektedir. Hastalığın tedavisinde ilaç uyumu en önemli noktalardandır. HIV/AIDS tedavisinde hasta eğitimi çok önemlidir. Bu çalışmanın amacı eğitim müdahalesi yapılan hasta grubunda ilaç uyumunun değerlendirilmesidir.

Yöntemler: Çalışma retrospektif verilerin analiz edildiği bir müdahale çalışması olarak gerçekleştirilmiştir. MayısTemmuz 2017 tarihleri arasında Dicle Üniversitesi Tıp Fakültesi Enfeksiyon Hastalıkları ve Klinik Mikrobiyoloji bölümünde izlenmekte olan 107 HIV/AIDS hastası çalışmaya dahil edilmiştir. Hastalığa özgü detaylı eğitim almayı kabul eden hastalar 1. Grup olarak değerlendirilmiştir. Eğitim almak istememiş olan 25 hasta ise (2. Grup/Kontrol grubu) standart poliklinik bilgilendirmesi almıștır. Her iki grubun eğitimleri aynı hekim tarafından verilmiștir. Hastaların tedavinin 3. ve 6. aylarındaki ilaç uyumları tablet sayma yöntemiyle değerlendirilmiştir.

Bulgular: Tedavi almakta olan 107 hastanın yaş ortalaması 28.6 yıldır. Hastaların 86'sı $(\% 80,4)$ erkektir. Hastaların eğitim durumları incelendiğinde $\% 8,4$ 'ü $(n=9)$ sadece okuryazar, \%67,3'ü $(n=72)$ ilk ve orta öğretim mezunu olarak tespit edilmiştir. Hastaların öğrenim durumları ile 3. ve 6. aydaki ilaç uyumları arasında istatistiksel olarak anlamlı bir fark tespit edilmemiștir (sırasıyla $p=0,159$ ve $p=0,274$ ). Günlük tablet sayısından bağımsız olarak, ilaç uyumu, eğitim verilenlerde istatistiksel olarak anlamlı düzeyde yüksek saptanmıştır ( $\mathrm{p}<0,001)$. 
Tartışma ve Sonuç: HIV enfeksiyonu olan hastalarda, hastalığa özgü eğitim vermek tablet sayısından ve temel öğrenim düzeyinden bağımsız olarak, ilaç uyumunu anlamlı düzeyde arttırmaktadır. Daha az sayıda tablet içeren rejimler kullanmak da ilaç uyumunu arttırmaktadır.

Anahtar kelimeler: insan immün yetmezlik virüsü; eğitim müdahalesi; ilaç uyumu; pozoloji

\title{
Does Effective Education Intervention Affects HIV Patients Compliance Independently from Drug Posology?
}

\begin{abstract}
Objective: According to 2017 records 17.000 people are infected with HIV (human immunodeficiency virus) in Turkey. Drug compliance is one of the most important points in the treatment of the disease. Patient training is very important in HIV / AIDS treatment. This study aimed to evaluate drug compliance in a patient group undergoing training intervention.

Methods: The study was conducted as a retrospective analysis of an intervention. Totally, 107 HIV / AIDS patients followed up at the Infectious Diseases and Clinical Microbiology Department of Dicle University Medical Faculty between May-July 2017 were included in the study. Patients who were evaluated as Group 1 received personalized detailed training, the other 25 patients (Group 2) took standard briefing. Patients' drug compliances evaluated by tablet counting method at third and sixth months of treatment.

Results: The mean age of 107 patients trained was 28.6 years. Eighty-six (80.4\%) of the patients were male. The educational status of the patients, $8,4 \%(n=9)$ were literate, $67,3 \%(n=72)$ studied primary and secondary education, no statistically significant difference was found between the educational status of the patients and drug compliance. ( $p=0,159$ and $p=0,274$, respectively). Regardless of the number of tablets per day, drug compliance was found to be statistically significantly higher in Group 1. ( $p<0,001)$

Discussion and Conclusion: In patients with HIV, providing disease-specific training significantly increases drug compliance regardless of the number of tablets and education level. Using of regimens containing fewer tablets increases drug compliance.
\end{abstract}

Keywords: human immunodeficiency virus; drug compliance; education intervention; posology.

\section{GİRIŞ}

Lentivirüs ailesinin bir üyesi olan HIV (Human Immmunodeficiency Virus) virüsünün HIV-1 ve HIV-2 olmak üzere iki tipi mevcuttur. HIV başlıca CD4 hücrelerini enfekte eder. HIV enfeksiyonunun seyri boyunca, CD4 hücre sayıları giderek azalır ve bağışıklık sistemi zayıflar. Bağışıklık sisteminin hastalıklarla mücadele edemeyecek kadar zayıf düşmesi sonucu, AIDS (Edinilmiş Bağışıklık Yetmezliği Sendromu) adı verilen durum ortaya çıkar ${ }^{1}$. Dünya Sağlık Örgütü (DSÖ) verilerine göre 2018 yllında dünya genelinde toplam 32 milyon kişinin HIV ile enfekte olduğu, 23,3 milyon kişinin ise antiretroviral tedavi aldığ bildirilmiştir ${ }^{2}$. HIV'in özelliklerinin belirlenmesi ile birlikte antiviral ilaçlar klinik kullanıma girmiş ve HIV enfeksiyonlarının tedavisinde Highly Active Anti-Retro-viral Therapy (HAART) adı verilen güçlü etkinlikte kombine tedavi rejimleri kullanılmaya başlanmıştır. $\mathrm{Bu}$ ilaç rejimleri günde ikili, üçlü, dörtlü tabletler șeklinde olabildiği gibi tek tablet rejimi (TTR) şeklinde de uygulanabilmektedir. HIV enfeksiyonu olan hastalarda kalıcı viral yanıtın gelişmesinde ilaç uyumunun rolü büyüktür. İlaç uyumu, hastalığa neden olan sorunu yönetebilecek kadar ilaç alınması, kaçırılan dozların ölçülmesi ve tedavi devam süresini de kapsayan dinamik bir süreç olarak 
tanımlanabilir. İlaç uyumu, hastanın tedavisi için gerekli olan minimum ilaç dozu ve süresinin sağlanmasına dayanır. HIV enfeksiyonu olan hastalarda ilaç uyumsuzluğu: virolojik kırılma, fırsatçı enfeksiyonların gelişimi ve antiretroviral direnç gibi olumsuz durumlara yol açar. Kronik hasta takibinde ilaç uyumunun hesaplanmasinda en objektif yöntem ilacın kandaki düzeyinin ölçülmesidir. Ancak maliyetli ve zaman-etkin olmayan bu yöntem yerine sıklıkla "Tablet sayma yöntemi" kullanılmaktadır. Tablet sayma yöntemi, subjektif ve manipülasyona açık bir yöntem olmasına karşın kronik hastalıkların ilaç uyumu takibinde güvenilir bir yöntem olarak kabul edilmektedir ${ }^{2,3}$.

Bu çalışmanın amacı, HIV ilaç uyumunda tedavi pozolojisi ile soruna yönelik etkin eğitim müdahalesi yapılmasının, uyum üzerine etkilerini değerlendirmektir.

\section{YÖNTEMLER}

Çalışma, verilerin retrospektif olarak hasta dosyalarına ait kayıtlardan elde edildiği bir çalışma olarak tasarlanmıştır. Çalışmaya, 1 Mayıs ile 31 Temmuz 2017 tarihleri arasında, Dicle Üniversitesi Enfeksiyon Hastalıkları ve Klinik Mikrobiyoloji kliniğinde HIV tedavisi almakta olan, 18-65 yaş arasındaki 107 hasta dahil edilmiştir. Hastalara ait temel demografik veriler hasta dosyaları ve hastane bilgi sisteminden elde edilmiştir. Klinikte rutin olarak HIV enfeksiyonu tanısı alan ve artık bu klinikte izlemi yapılacak olan tüm hastalara, kontrol vizitlerine gelen daha önceden tedavi almış/almamış tüm hastalara hastalık ile ilgili detaylı bir eğitim almayı isteyip istemedikleri sorulmaktadır. Hastaların ilaç uyumları da tablet sayma yöntemi ile belirlenen vizitlerde kontrol edilmektedir. Çalışmaya dahil edilen hastalardan 14'ünün HIV-RNA düzeyi >50 IU/ml iken, geri kalan 93'ü HIV RNA negatif hastalardır. Klinikte izlenen hastaların rutin takip periyodu içerisinde kendilerine hastalığa özgü detaylı bir eğitim alıp isteyip istemediklerine dair 4 soruluk bir anket uygulanmaktadır. Çalışmaya dahil edilen 107 hastanın da tamamına, dosya kayıtlarında mevut olan anket formu verilmiştir. Bu ankette sorulan sorular Tablo I'de sunulmuştur. Bu hastalardan 82'si verilen anketi doldurmuş, 25'i ise anket doldurmayı da (ve silindi) detaylı bir eğitim almayı da kabul etmemiştir. Ardından anket dolduran hastalara ankette verdikleri cevaplara göre şekillenen "kişiye özel eğitim" verilirken, anket doldurmayan 25 hastaya (standart silindi) "standart poliklinik bilgilendirmesi" yapılmıştır.

Tablo I: Ankette sorulan sorular
\begin{tabular}{|c|l|}
\hline $\begin{array}{c}\text { Soru } \\
\text { numarası }\end{array}$ & \multicolumn{1}{c|}{ Sorular } \\
\hline 1 & $\begin{array}{l}\text { HIV hastalığı hakkında yeterince } \\
\text { bilgilendirildiniz mi? }\end{array}$ \\
\hline 2 & $\begin{array}{l}\text { Kullanacağınız ilaçların kullanım şekli ve süresi } \\
\text { hakkında bilgi sahibi misiniz? }\end{array}$ \\
\hline 3 & $\begin{array}{l}\text { İlaçları kullanmadığınız zaman ne tür sorunlar } \\
\text { olabileceği konusunda bilgilendirildiniz mi? }\end{array}$ \\
\hline 4 & $\begin{array}{l}\text { Bir ay içinde kaç gün ilaç kullanmama hakkınız } \\
\text { var biliyor musunuz? }\end{array}$ \\
\hline
\end{tabular}

Kişiye özel eğitim, HIV enfeksiyonu ile ilgili genel bilgilendirmeyi, hastalığın bulaş yollarını, kullanılan ilaçların genel özelliklerini, ilaç uyumunun anlamını ve hastalıkta uyumun önemini kapsamaktadır.

Standart bilgilendirme ise hastanın kullandığ ilaca dair kullanım özelliklerinin anlatıldığı bir poliklinik bilgilendirmesi şeklindedir. Eğitim ve bilgilendirme her iki grup için hep aynı hekim tarafından yapılmıştır.

Eğitim ve bilgilendirmenin ardından hastalardan rutin poliklinik kontrolüne gelirken beraberlerinde getirdikleri ilaç kutuları ile tablet sayma yöntemi kullanılarak 3. ay ile 6. ay sonunda ilaç uyumu değerlendirilmiştir. Sekiz hasta 3. ay vizitinde ilaç kutularını getirmedikleri için çalışma dışı bırakılarak analizlere 99 hasta üzerinden devam edilmiştir. Bu 99 hastanın 76’sı $(\% 76,7)$ anketi dolduran ve kişiye özel eğitim alan hastalar (grup 1: çalışma grubu) iken, 23'ü $(\% 23,3)$ anketi doldurmayan ve standart 
bilgilendirme alan hastalardır (grup 2: kontrol grubu). Çalışmanın başlangıç noktasında, bu hastaların 7'sinin HIV RNA'sı pozitif iken 92'sinin HIV RNA'sı negatiftir. Çalışmaya dâhil edilen 99 hasta içinden grup 1'deki 76 hastanın tedavi rejimlerinde kullandığı günlük tablet sayılarına göre dağılımı; günlük tek tablet kullanan 16 (\%21,1), iki tablet kullanan 34 $(\% 44,7)$, üç tablet kullanan $13(\% 17,1)$ ve dört tablet kullanan $13(\% 17,1)$ hasta şeklindedir. Grup 2'deki hastaların kullandığı günlük tablet sayılarına göre dağılımı ise: Günlük tek tablet kullanan $4(\% 17,4)$, iki tablet kullanan 8 $(\% 34,8)$, üç tablet kullanan $6(\% 26,1)$ ve dört tablet kullanan $5(\% 21,7)$ hasta şeklindedir.

Tablet sayma yönteminde, tedavi sürecinde hastaların günlük aldıkları tablet sayısının, almaları gereken tablet sayısına oranı yüzde ile ifade edilerek ilaç uyumu hesaplanmıştır. Eğitim alan (grup 1) ve eğitim almadan bilgilendirme yapılan (grup 2) hastaların, 3. ve 6. aylardaki ilaç uyumları hasta kayıtlarından alınmış ve hesaplanan değerler yüzde olarak kaydedilmiştir. Ayrıca eğitim alan (grup 1) ve almayan (grup 2) hastalarda eğitim sonrası 3. aydaki ve 6. aydaki HIV RNA düzeyleri de kayıt altına alınmıştır. HIV RNA düzeylerinin belirlenmesinde amaç ilaç uyumu ile ilgili olası bir manipülasyonu fark etmektir.

Veriler SPSS-21 paket programı ile analiz edilmiştir. Verilerin değerlendirilmesinde tanımlayıcı istatistikler kullanılmış ve veriler ortanca (en küçük-en büyük değer), sayı ve yüzde dağılımı ile sunulmuştur. Verilerin karşılaştırılmasında Ki-kare ve Kruskal Wallis testleri kullanılmıştır. İstatistiksel anlamlılık düzeyi $\mathrm{p}<0,05$ olarak kabul edilmiştir.

Çalışma Dicle Üniversitesi Tıp Fakültesi girişimsel olmayan klinik araştırmalar kurulunun 30.05.2019 tarih ve 141 numaralı kararı ile onaylanmıştır.

\section{BULGULAR}

HIV tedavisi almakta olan 107 hastanın yaş ortalaması 28,56 $\pm 9,40$ ve ortanca değeri 27 (17-67) olup hastaların 86'sı $(\% 80,4)$ erkek, 21 'i $(\% 19,6)$ kadın idi. Bu hastaların eğitim durumları incelendiğinde, $\% 8,4$ ü $(n=9)$ sadece okur-yazar, \%67,3'ü $(n=72)$ ilk ve orta öğretim mezunu, \%16,8'i $(n=18)$ lise mezunu ve \%7,5'i $(n=8)$ yüksekokul ve üniversite mezunu olarak tespit edilmiştir. İlaç uyumunun hesaplandığı 99 hastanın yaş ortalaması 28,39 \pm 9,54 (17 67) olup, bu hastaların 79'u $(\% 79,8)$ erkek, 20 'si $(\% 10,2)$ kadındır. Bu hastalardaki eğitim düzeyi dağılımı ise şu şekildedir: \%8,1'i (n=8) sadece okur-yazar, \%67,7'si $(n=67)$ ilk ve orta öğretim mezunu, \%16,2'si $(n=16)$ lise mezunu ve \%8,1'i (n=8) yüksekokul ve üniversite mezunudur.

Hastaların öğrenim durumları ile üçüncü ve altıncı aydaki ilaç uyumları arasında istatistiksel anlamlı bir fark tespit edilmemiştir (sırasiyla $p=0,159$ ve $p=0,274$ ).

Günlük tablet sayısından bağımsız olarak, ilaç uyumunun eğitim verilenlerde, verilmeyenlere göre istatistiksel olarak anlamlı düzeyde yüksek olduğu tespit edilmiştir $(p<0,001)$. Tablo II'de eğitim verilme durumuna ve günlük kullanılan tablet sayısına göre, üç ve altıncı aylardaki ilaç uyum yüzdeleri gösterilmektedir.

Çalışmada, üç ve altıncı aylarda hastaların kullandığı tedavilerdeki tablet sayıları ile ilaç uyumları arasında istatistiksel anlamlı fark tespit edilmiştir. Üçüncü ayda, bir tablet kullananlarda ve iki tablet kullananlarda ilaç uyumunun, dört tablet kullananlara göre istatistiksel olarak anlamlı düzeyde yüksek olduğu belirlenmiştir ( $p=0,001$ ve $p=0,001)$. Altıncr ayda da ilaç uyumu, bir tablet kullananlarda dört tablet kullananlara göre $(\mathrm{p}=0,003)$, iki tablet kullananlarda üç tablet kullananlara göre $(p=0,027)$, iki tablet kullananlarda dört tablet kullananlara göre $(p=0,002)$ anlamlı olarak daha yüksek bulunmuştur. Hastaların kullandıkları tedavi 
rejimlerinin günlük tablet sayısı ile ilaç uyumları arasındaki ilişki Tablo III'te sunulmuştur.

Tablo II: Üç ve altıncı aylarda, eğitim verilme durumuna ve günlük kullanılan tablet sayısına göre ilaç uyum yüzdelerinin dağılımı

\begin{tabular}{|c|c|c|c|c|c|c|}
\hline \multirow{2}{*}{$\begin{array}{c}\text { İlaç } \\
\text { kullanımı }\end{array}$} & \multicolumn{3}{|c|}{ 3. ay ilaç uyum yüzdesi (\%) } & \multicolumn{3}{|c|}{ 6. ay ilaç uyum yüzdesi (\%) } \\
\hline & $\begin{array}{c}\text { Eğitim } \\
\text { verilenler } \\
\text { (Grup 1) } \\
(n=76)\end{array}$ & $\begin{array}{c}\text { Eğitim } \\
\text { verilmeyenler } \\
\text { (Grup 2) } \\
(n=23)\end{array}$ & P değeri & $\begin{array}{c}\text { Eğitim } \\
\text { verilenler } \\
\text { (Grup 1) } \\
(n=76)\end{array}$ & $\begin{array}{c}\text { Eğitim } \\
\text { verilmeyenler } \\
\text { (Grup 2) } \\
(n=23)\end{array}$ & P değeri \\
\hline $\begin{array}{c}\text { 1 tablet } \\
\text { kullananlar }\end{array}$ & $87(80-92)$ & $71,5(67-76)$ & $<0,001$ & $87(78-91)$ & $71(63-72)$ & $<0,001$ \\
\hline $\begin{array}{c}\text { 2 tablet } \\
\text { kullananlar }\end{array}$ & $86,5(79-90)$ & $67,5(64-78)$ & $<0,001$ & $87(80-95)$ & $67(61-78)$ & $<0,001$ \\
\hline $\begin{array}{c}\text { 3 tablet } \\
\text { kullananlar }\end{array}$ & $86(73-9)$ & $66,5(62-75)$ & $<0,001$ & $85(72-90)$ & $65,5(60-72)$ & $<0,001$ \\
\hline $\begin{array}{c}4 \text { tablet } \\
\text { kullananlar }\end{array}$ & $80(65-87)$ & $67(63-72)$ & $<0,019$ & $8065-87)$ & $67(64-71)$ & $<0,014$ \\
\hline
\end{tabular}

Tablo III: Hastaların kullandıkları tedavi rejimlerinin günlük tablet sayısı ile ilaç uyum yüzdeleri arasındaki ilişki

\begin{tabular}{|l|c|c|c|c|c|}
\hline $\begin{array}{l}\text { İlaç uyum } \\
\text { yüzdesi }\end{array}$ & $\begin{array}{c}\mathbf{1} \text { tablet } \\
\text { kullananlar }\end{array}$ & $\begin{array}{c}\mathbf{2} \text { tablet } \\
\text { kullananlar }\end{array}$ & $\begin{array}{c}\text { 3 tablet } \\
\text { kullananlar }\end{array}$ & $\begin{array}{c}\text { 4 tablet } \\
\text { kullananlar }\end{array}$ & P değeri \\
\hline 3. ay & $86(67-92)^{1}$ & $86(64-90)^{2}$ & $81(62-90)$ & $77(63-87)^{3}$ & $\mathbf{0 , 0 0 1}$ \\
\hline 6. ay & $86(63-91)^{4}$ & $86,5(61-95)^{5}$ & $80(60-90)^{6}$ & $75,5(64-87)^{7}$ & $\mathbf{0 , 0 0 1}$ \\
\hline
\end{tabular}

1\&3: $\mathrm{p}=0,001 ; 2 \& 3: \mathrm{p}=0,001 ; 4 \& 7: \mathrm{p}=0,003 ; 5 \& 6: \mathrm{p}=0,027 ; 5 \& 7: \mathrm{p}=0,002$

Tablo IV: Üç ve altıncı aylardaki HIV RNA durumuna (pozitif/negatif) göre ilaç uyum yüzdelerinin dağılımı

\begin{tabular}{|l|c|c|c|c|c|c|}
\hline & $\begin{array}{c}\text { 3. ayda HIV RNA } \\
\text { negatif olan } \\
(\mathbf{n = 8 5})\end{array}$ & $\begin{array}{c}\text { 3. ayda HIV } \\
\text { RNA pozitif } \\
\text { olan }(\mathbf{n = 1 4 )}\end{array}$ & P değeri & $\begin{array}{c}\text { 6. ayda HIV RNA } \\
\text { negatif olan } \\
(\mathbf{n = 8 4 )}\end{array}$ & $\begin{array}{c}\text { 6. ayda HIV RNA } \\
\text { pozitif olan } \\
(\mathbf{n}=\mathbf{1 5})\end{array}$ & P değeri \\
\hline İlaç uyum yüzdesi & $86(62-92)$ & $70(64-87)$ & $<\mathbf{0 , 0 0 1}$ & $86(60-95)$ & $72(62-89)$ & $\mathbf{0 , 0 0 4}$ \\
\hline (\%) & & & & & \\
\hline
\end{tabular}


Çalışmanın 3. ve 6. ayında test edilen HIV RNA düzeyleri ve hastaların ilaç uyum yüzdeleri arasındaki ilişki şöyledir: 3. ayda HIV RNA negatif olan hastalarda, ilaç uyumu HIV RNA'sı pozitif olan hastalara göre istatistiksel olarak anlamlı düzeyde yüksektir $(\mathrm{p}=0,001)$. Altıncı ayda HIV RNA negatif olan hastalarda, ilaç uyumu HIV RNA'sı pozitif olan hastalara göre istatistiksel olarak anlamlı düzeyde yüksektir $(\mathrm{p}=0,004)$ (Tablo IV).

Tablo V: Tedavi uyumunun üç ve altıncı aylardaki HIV RNA değișikliğine göre dağılımı

\begin{tabular}{|c|c|c|}
\hline HIV-RNA & $\begin{array}{l}\text { Tedavi uyumu yüzdesi } \\
\text { Ortanca (en küçük - en } \\
\text { büyük) }\end{array}$ & P değeri \\
\hline $\begin{array}{l}0,3 \text { ve } 6 . \text { ayda pozitif olanlar }{ }^{1} \\
(n=7)\end{array}$ & $66(62-87)$ & \multirow{4}{*}{0,005} \\
\hline $\begin{array}{l}3 \text { veya } 6 . \text { ayda pozitifleşenler } \\
(n=8)\end{array}$ & $78,5(66-89)$ & \\
\hline $\begin{array}{l}3 \text { veya 6. ayda negatifleșenler }{ }^{2} \\
(n=7)\end{array}$ & $83(60-88)$ & \\
\hline $\begin{array}{l}0,3 \text { ve } 6 . \text { ayda negatif olanlar }{ }^{3} \\
(\mathrm{n}=84)\end{array}$ & $84(61-95)$ & \\
\hline
\end{tabular}

1\& 3: $\mathrm{p}=0,005$

Çalışmanın 3. ve 6. aylarında başlangıca göre HIV RNA değişimlerinin tedavi uyumu ile ilişkisi irdelendiğinde, tedavi uyum yüzdeleri ile HIV RNA değişimi arasında istatistiksel anlamlı fark tespit edilmiştir. Başlangıçta ve takiplerinde HIV RNA negatif olanların "tedavi uyumları", başlangıçta ve takiplerinde HIV RNA pozitif olanlara göre istatistiksel olarak anlamlı bir şekilde yüksek bulunmuştur $(p=0,005)$ (Tablo V).

\section{TARTIŞMA}

İlaç uyumu, HIV enfeksiyonunun yönetimini etkileyen önemli bir faktördür ${ }^{2,3}$. İlaç uyumu ile ilgili olarak 2010-2015 yılları arasında, ülkemizde ve yurt dışında HIV/AIDS hastalarında yapılmış 11 araştırmanın analiz edildiği bir çalışmada, ilaç uyumunun, viral baskılanmanın devamlılığının sağlanmasında, sağlık düzeyinin iyileşmesinde ve yaşam kalitesinin artmasında katkısının olduğu bildirilmiştir ${ }^{4}$ İlaç uyumunun azalması sonucu, ilaçlara direnç gelişme riski artmakta, tedavide kullanılabilecek ilaç rejimi seçenekleri azalmakta ve tedavi başarısı düşmektedir. Hindistan'dan yapılan bir çalışmada, 54 yaşındaki ilaç uyum düzeyi düşük bir hastada, Abacavir, Didanosine, Zidovudine, Tenofovir, Stavudine, Emtricitabine, Lamivudine, Nevirapine ve Efavirenz ilaçlarına direnç geliştiği saptanmıştır ${ }^{5}$. Antiretroviral tedavi (ART) kullanılarak, kalıcı viral baskılanma elde etmek için tedaviye en az \%95'lik uyum gerekmektedir. Güney Afrika'da yapılan bir çalışmada, 18-35 yaşları arasındaki HIV enfeksiyonu olan 281 hastada ilaç uyumu ile ilişkili faktörler araştırılmış ve hastaların genel ART uyumunun \%87,2 $(n=245)$ olduğu bulunmuştur. Yine aynı çalışmada hastaların, unuttuğu için, kendini daha iyi hissetmek için, tedavinin bitmesinden korktukları için ilaçları almadığ hastaların \%3,9'u ise bir neden bildirmemiștir. Bunun yanında, üniversite mezunu olan, 30-35 yaş aralığında olan, ilaçlara kolay ulaşabilen ve gelir düzeyi yüksek hastalarda, ilaç uyumu anlamlı ölçüde yüksek bulunmuştur ${ }^{6}$. Usman SA ve arkadaşlarının yaptığı bir çalışmada da ilaç uyumsuzluğunun en sık nedeninin (\%58) unutkanlık olduğu bildirilmiştir. Bu çalışmada ise çarpıcı olarak öğrenim düzeyi ve gelir düzeyi yüksek bireylerde ilaç uyumunun düşük olduğu gözlenmiştir ${ }^{7}$. İran'da, HIV ile enfekte hastalarda yapılan bir anket çalışmasında, hastaların ilaç uyumsuzluğunun en sık nedenlerinin, unutkanlık, yüksek ilaç dozu, ART tedavisinin önemi ve değeri hakkındaki bilgi eksikliği ve ulaşım problemleri olduğu tespit edilmiștir8. DSÖ tarafından Hindistan'da yapılan bir çalışmada, ART tedavisi alan toplam 440 yetişkin hasta seçilmiş, ilaç sayma yöntemi kullanılarak ilaç uyumu ve uyumu etkileyen faktörler araştırılmıştır. Bu çalışmada ilaç uyumu \%81,3 olarak belirlenmiștir. İlacın ulaşılabilirliği, doktora sık danışabilme imkanı, 
ilacın yan etkiye neden olmaması, hastanın algıladığı sağlık durumundaki iyileşme, anlamlı olarak ART (ilaç çıkarıldı) uyumu ile ilişkili olarak bulunmuştur. Kullanılan ilaç rejimi açısından yapılan değerlendirmede, ilaç uyumunun Tenofovir, Lamivudine and Efavirenz (TLE) rejimi kullananlarda \%75,9 olduğu; Zidovudine, Lamivudine and Nevirapine (ZLN) rejimi ve Efavirenz içermeyen rejimler ile tedavi edilenlerde ise \%87,8 olduğu ortaya konmuştur. CD4 sayıları değerlendirildiğinde ise ilaç uyumu olan hastaların \%27,1'inde, uyumsuz olan hastaların ise \%72,9'unda CD4 sayısında düşme gözlenmiştir ${ }^{9}$. Tüm bu çalışmalar, HIV enfeksiyonu olan hastalarda, ilaç uyum oranının, uzun süreli viral yükü baskılama açısından hala tatmin edici seviyelerin altında olduğunu göstermektedir. $\mathrm{Bu}$ nedenle ilaç eğitim müdahalesinin ilaç uyumu üzerindeki etkisinin araştırılması önemli bir konudur. Goujard C ve arkadaşları bir çalışmada, bireysel eğitim müdahalesinin, HIV ile enfekte hastalarda antiviral tedaviye uyum, hastanın yaşam kalitesi ve terapötik yanıt üzerindeki etkisini araştırmıştır. Bu çalışmada, eğitim programına katılan deney grubu ve standart bakım alan kontrol grubu karşılaştırılmış; yaşl, gelir düzeyi yüksek ve sigara içmeyen hastalarda ilaç uyumunun daha iyi olduğu gözlenmiştir. Hastaların 6. aydaki bilgi düzeylerinin 12 . ve 18 . ayda da devam ettiği bildirilmiştir. Deney grubundaki hastalarda ilaç uyumunun daha iyi olduğu belirlenmiștir. Deney grubunun \%56'sinın ve kontrol grubunun \%50'sinin sağlı durumunun iyileștiği gözlenmiștir. Bununla birlikte, CD4 hücre sayısı ve plazma viral yükü üzerinde önemli bir etki gösterilmemiştir. Yazarlar, bir eğitimsel müdahale ile antiretroviral rejimlere uyumu arttırmanın, sağlık durumunu iyileștirmenin mümkün olduğunu ve eğitime erken dönemde başlanması gerektiğini savunmuştur ${ }^{10}$. Van Servellen G ve arkadaşları tarafından yapılan bir diğer çalışmada, düşük gelirli, HIV ile enfekte, antiretroviral tedavi alan
Latin bireylerde sağlı okur-yazarlığını arttırmaya yönelik bir programın kabul edilebilirliği ve etkinliği değerlendirilmiştir. Programın etkinliğinin değerlendirilmesi için, eğitim kartları verilen müdahale $(n=41)$ grubu ve sadece standart bakım ( $\mathrm{n}=40)$ grubu, başlangıçta ve 6 haftalık aralıklarla analiz edilmiştir. Müdahale grubu katılımcıları, HIV/AIDS önlemleri, tedavi, HIV terimlerinin anlaşılması konusunda önemli bir gelişme göstermiştir ancak uyum ve davranışlarda önemli bir değişiklik göstermemiştir ${ }^{11}$.

Bizim çalışmamız, bilgimiz dâhilinde ülkemizde HIV enfeksiyonu olan kişilere özgü eğitim müdahalesinin, ilaç uyumuna etkisinin araştırılması amacıyla yapılan ilk çalışmadır. Ayrıca dünya literatüründe, HIV enfeksiyonlu hastalarda ilaç uyumunu altı ay gibi uzun bir periyodda değerlendiren sınırlı sayıda çalışma mevcuttur. $\mathrm{Bu}$ çalışmada, günlük kullanılan tablet sayısından bağımsız olarak, ilaç uyumunun eğitim verilenlerde, verilmeyenlere göre istatistiksel olarak anlamlı düzeyde yüksek olduğu tespit edilmiştir. Bu sonuç ilaç uyumunda kişiye özel eğitimin önemini açık şekilde ortaya koymaktadır. Hastaların temel öğrenim durumları ile ilaç uyumları arasında anlamlı bir fark tespit edilmemiş olması, temel öğrenim düzeyi ne olursa olsun hastaların ilaç uyumunu eğitim ile arttırmanın mümkün olduğunu göstermektedir. Antiretroviral tedavi alan hastalara ilaç uyumunun öneminin, uyum oranının yüksek ve düşük olmasının hangi olumlu ve olumsuz sonuçlara yol açacağının anlatılması gereklidir. İlaç uyumunu olumsuz yönde etkileyebilecek faktörler belirlenmeli ve bu faktörler ortadan kaldırılmalıdır ${ }^{4}$.

Aldir I ve arkadaşları bir derlemede, HIV ile enfekte hastalarin tedavisinde kullanılan TTR'ni etkinlik, güvenilirlik, uyum, yaşam kalitesi ve farmakoekonomik açıdan değerlendirmek için, PubMed, IndexRevMed ve Cochrane'de mevcut verileri gözden geçirmiştir. Günde bir tablet şeklinde verilen kombinasyonların, antiretroviral tedaviyi basit 
hale getirdiğini, uyumun artmasına katkıda bulunduğunu ve hastaların yaşam kalitesini arttırdığını, ekonomik yarar sağladığını ortaya koymuşlardır ${ }^{12}$. Bizim çalışmamızda, hastaların tedavi rejimlerinde günlük kullandıkları tablet sayıları ile ilaç uyumları arasında istatistiksel anlamlı fark tespit edilmiştir. Üçüncü (ayda çıkarıldı) ve altıncı aydaki ilaç uyumları, bir tablet kullananlarda, 3-4 tablet kullananlara göre anlamlı düzeyde yüksektir. $\mathrm{Bu}$ da ilaç uyumunu arttırmada az sayıda tablet içeren rejimlerin önemini açığa çıkarmaktadır.

HIV ile enfekte hastalarda, HIV RNA takibi, hastalığın tedaviye yanıtının izlenmesinde ve ilaç uyumunun değerlendirilmesinde objektif bir kriterdir. Tedaviye uyumun azalması plazma HIV RNA düzeylerinin artmasına neden olurken, tedaviye uyumun artması HIV RNA düzeylerinde azalmaya neden olmaktadır ${ }^{4,6}$. Tedaviye uyum oranı ile virolojik baskılanma arasında anlamlı ilişki olduğu; ilaç uyumundaki \%10’luk artışın virolojik başarısızlık riskini \%73 azalttığı bildirilmiştir ${ }^{13-15}$. Çalışmamızda, 3. ayda ve 6. ayda yapilan HIV RNA takiplerinde, HIV RNA negatif olan hastalarda, ilaç uyumlarının, HIV RNA pozitif hastalara göre anlamlı düzeyde yüksek olduğu bulunmuştur. Ayrıca, hastaların tedaviye uyumları değerlendirildiğinde, başlangıçta ve takiplerinde HIV RNA negatif olanların tedavi uyumları, başlangıçta ve takiplerinde HIV RNA pozitif olanlara göre istatistiksel olarak anlamlı bir şekilde yüksek bulunmuştur. Bu sonuç, hastalarda ilaca uyum oranının artmasının, tedavi yanıtını iyi yönde etkilediğini ve tablet sayma yöntemi kullanılarak ölçülen ilaç uyum düzeyinin gerçeği büyük oranda yansıttığını göstermektedir.

Sonuç olarak; ilaç uyumu, HIV enfeksiyonunun yönetimini etkileyen faktörlerin başında gelmektedir. HIV enfeksiyonu olan hastalarda, hastalığa özgü olarak eğitim vermek, tablet sayısından ve temel öğrenim düzeyinden bağımsız olarak ilaç uyumunu anlamlı düzeyde arttırmaktadır. Az sayıda tablet içeren rejimler kullanmak da ilaç uyumunu arttıracaktır. HIV RNA düzeylerinin ölçümü hastalığın takibi, tedaviye uyumun ve ilaç uyumunun değerlendirilmesinde değerli bir yöntemdir. İlaç uyumu iyi olan hastalarda HIV RNA düzeylerindeki negatiflik oranları yüksektir. Tablet sayma yöntemi, ilaç uyumunu değerlendirmede yararlı bir yöntemdir ve ilaç uyumu, tedavi yanıtını olumlu yönde etkilemektedir.

Çıkar Çatışması Beyanı: Yazarlar çıkar çatışması olmadığını bildirmişlerdir.

Finansal Destek: Bu çalışma her hangi bir fon tarafından desteklenmemiştir.

Declaration of Conflicting Interests: The authors declare that they have no conflict of interest.

Financial Disclosure: No financial support was received.

\section{KAYNAKLAR}

1. Çelen MK, Sayan M, Dal T, et al. Molecular epidemiology of HIV-1 strains in the south-east and east of Turkey. Asian Pac J Trop Biomed 2015; 5: 773-7.

2. World Health Organization (WHO). Erişim tarihi: 10 Temmuz 2019. Available from: https://www.who.int/news-room/factsheets/detail/hiv-aids

3. Osterberg L, Blaschke T. Adherence to medication. N Engl J Med 2005; 353: 487-97.

4. Claxton, AJ, Cramer J, Pierce C. A systematic review of the associations between dose regimens and medication compliance. Clin Ther 2001; 23: 1296-310.

5. Aydın E, Koç A. HIV (+) /AIDS hastalarında antiretroviral tedaviye uyumun önemi (Literatür Çalışması). Jinekoloji-Obstetrik ve Neonatoloji Tıp Dergisi 2017; 14.

6. Masikini P, Mpondo BCT. HIV Drug resistance mutations following poor adherence in HIV-infected patient: a case report. Clin Case Rep 2015; 3: 353-35.

7. Mabunda K, Ngamasana EL, Babalola JO, Zunza M, Nyasulu P. Determinants of poor adherence to antiretroviral treatment using a combined effect of age and education among human immunodeficiency virus 
infected young adults attending care at Letaba Hospital HIV Clinic, Limpopo Province, South Africa. Pan Afr Med J 2019; 18: 37.

8. Usman SA, Shehu A, Ajumobi O, et al. Predictors of nonadherence to antiretroviral therapy among HIV patients in secondary health care facilities in Kano State- Nigeria: a case-control study. Pan Afr Med J $2019 ; 21 ; 32: 3$.

9. Morowatisharifabad MA, Movahed E, Farokhzadian J, et al. Antiretroviral therapy adherence and its determinant factors among people living with HIV/AIDS: a case study in Iran. BMC Res Notes 2019; 22: $12: 162$.

10. Alvi Y, Khalique N, Ahmad A, Khan HS, Faizi N. World health organization dimensions of adherence to antiretroviral therapy: a study at antiretroviral therapy centre, Aligarh. Indian J Community Med 2019 Apr-Jun; 44: $118-24$.
11. Goujard C, Bernard N, Sohier N, et al. Impact of a patient education program on adherence to HIV medication: a randomized clinical trial. J Acquir Immune Defic Syndr 2003; 1; 34: 191-4.

12. Court R, Leisegang R, Stewart A, et al. Short term adherence tool predicts failure on second line protease inhibitor-based antiretroviral therapy: an observational cohort study. BMC Inf Dis 2014; 4: 664.

13. Aldir I, Horta A, Serrado M. Single-tablet regimens in HIV: does it really make a difference? Curr Med Res Opin 2014 Jan; 30: 89-97.

14. Van Servellen G, Carpio F, Lopez M, et al. Program to enhance health literacy and treatment adherence in low-income HIV-infected Latino men and women. AIDS Patient Care STDS 2003 Nov; 17: 581-94.

15. Parienti JJ, Tran AB, Duval X, et al. Adherence profiles and therapeutic responses of treatment-naive HIVinfected patients starting boosted Atazanavir-based therapy in the ANRS 134-COPHAR 3 Trial. ACS Infect Dis 2013; 57: 2265-71. 